\title{
Understanding Diversity
}

Prof. dr. D.L. van Knippenberg

Inaugural Address Series Research in Management

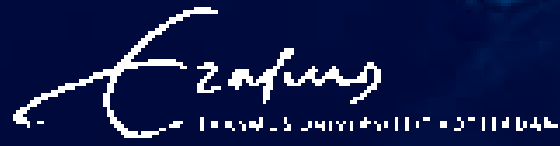


Understanding Diversity 


\section{Bibliographic data and classifications}

\section{Abstract}

Library of Congress Classification

(LCC)

http://lcweb.loc.gov/catdir/cpso/lcco/lcco_h.pdf

HF 5001-6182

HF 5546-5548.6, HF 5549-5549.5 + HD 58.7

HF 5001-6182

HF 5437.A2-Z

Journal of Economic Literature

(JEL)

http://www.aeaweb.org/journal/jel_class_system.html

M

M 10, L 2, M12

L25

Gemeenschappelijke Onderwerpsontsluiting (GOO)

Classification GOO

85.00

$85.05,85.08,85.62$

85.08

Keywords GOO

redex (vorm)

Free keywords
Bedrijfskunde / Bedrijfseconomie

Organisatiegedrag, groepsprocessen, diversiteit,

Diversity, group performance, group composition, team performance, team composition, social categorization, group decision making,

information elaboration

Erasmus Research Institute of Management (ERIM)

RSM Erasmus University

Erasmus School of Economics

Erasmus University Rotterdam

Internet: www.erim.eur.nl

ERIM Electronic Series Portal: http:hdl.handle.net/1765/1

Inaugural Addresses Research in Management Series

Reference number ERIM: EIA-2007-030-ORG

ISBN 90-5892-149-9

() 2007, Daan van Knippenberg

Design and layout: B\&T Ontwerp en advies (www.b-en-t.nl)

Print: Haveka (www.haveka.nl)

All rights reserved. No part of this publication may be reproduced or transmitted in any form or by any means electronic or mechanical, including photocopying, recording, or by any information storage and retrieval system, without permission in writing from the author(s). 


\title{
Understanding Diversity
}

\author{
Inaugural Address \\ Address given in shortened form \\ at the occasion of accepting the appointment as \\ Full Professor of Organizational Behavior \\ at RSM Erasmus University, Erasmus University Rotterdam \\ on Friday, October 12, 2007 \\ by \\ Prof. dr. D.L. van Knippenberg
}

RSM Erasmus University

Erasmus University Rotterdam

P.O. Box 1738

3000 DR Rotterdam

The Netherlands

E-mail: dvanknippenberg@rsm.nl

Erasmus Centre for Leadership Studies

www.erim.eur.nl/leadership 


\section{Samenvatting}

De belangrijkste vraag in diversiteitsonderzoek is hoe verschillen tussen groepsleden groepsprocessen en -prestaties beïnvloeden. Meer dan 50 jaar onderzoek naar diversiteit heeft duidelijk gemaakt dat diversiteit zowel positieve als negatieve effecten kan hebben op prestaties, maar onderzoek en praktijk worstelen nog steeds om modelen te formuleren die de uiteenlopende effecten van diversiteit kunnen verklaren en een leidraad bieden voor het management van diversiteit. Het CategorisatieElaboratie Model (CEM) richt zich op dit probleem. Het CEM stelt dat de effecten van werkgroep-diversiteit op groepsprestaties begrepen kunnen worden vanuit twee processen die onafhankelijk en in interactie invloed uitoefenen: elaboratie van taakrelevante informatie en sociale categorisatie. Diversiteit heeft positieve effecten op prestaties voor zover het tot de uitwisseling en integratie van taak-relevante informatie (elaboratie) leidt. Tegelijkertijd kan diversiteit schadelijk zijn voor prestaties voor zover het leidt tot "wij-zij" tegenstellingen (sociale categorisatie) en een negatieve houding ten opzichte van andere groepen - in het bijzonder omdat deze negatieve houding elaboratie-processen verstoort. Het CEM identificeert ook factoren waarvan het optreden van elaboratie- en sociale categorisatie-processen afhankelijk is, factoren die duidelijke invalshoeken voor diversiteits-management bieden. 


\section{Abstract}

The key question in diversity research is how differences between group members affect work group process and performance. Over 50 years of research have made clear that diversity can have positive as well as negative effects on performance, but research and practice are still struggling to formulate models that are able to make sense of these diverging effects and that offer clear guidance in how to manage diversity. The Categorization-Elaboration Model (CEM) addresses this issue. The CEM proposes that the effects of work group diversity on group performance should be understood in terms of two processes that have independent and interactive effects: elaboration of task-relevant information and social categorization. Diversity may have positive effects on performance to the extent that it engenders the exchange and integration of taskrelevant information (elaboration). At the same time, diversity may be detrimental to performance to the extent that it engenders "us-them" distinctions (social categorization) and intergroup biases - especially because these intergroup biases disrupt information elaboration processes. The CEM also identifies the factors on which the occurrence of elaboration and social categorization processes is contingent, factors that may offer clear angles for the management of diversity. 


\section{Content}

Work Group Diversity: A Brief Review of the Field 11

$\begin{array}{ll}\text { The Social Categorization Perspective } & 12\end{array}$

The Information/Decision Making Perspective $\quad 13$

But Where is the Evidence? $\quad 14$

The Categorization-Elaboration Model of

$\begin{array}{ll}\text { Group Diversity and Performance } & 16\end{array}$

$\begin{array}{ll}\text { Stimulating Information Elaboration } & 17\end{array}$

Refining Our View of Social Categorization Processes 18

$\begin{array}{ll}\text { Diversity Beliefs } & 24\end{array}$

Understanding Diversity - In Conclusion $\quad 27$

$\begin{array}{ll}\text { A Word of Thanks } & 28\end{array}$

$\begin{array}{ll}\text { References } & 30\end{array}$

Erasmus Research Institute of Management (ERIM) 33 


\section{Mijnheer de Rector Magnificus, \\ Geacht College van Dekanen, \\ Distinguished colleagues, \\ Ladies and gentlemen,}

It has long been noted that organizations may take many different forms. With increasing globalization and growing possibilities in information and communication technology, there seems to be an ever-increasing variety in the ways organizations are structured, in organizational goals and missions, and in the way members of the organization communicate and coordinate their work. However, no matter what their mission is, no matter what their structure is, no matter what their means of communication or coordination of the activities of members is, all organizations have at least one thing in common: All organizations are made up of people. This places - or should place - organizational behavior, the study of the behavior of individuals and groups in organizations, center-stage in management science. No matter what an organization aims to accomplish, a core factor in the organization's ability to be effective in accomplishing its goals are its human resources. The knowledge, skills, abilities, attitudes, motivations, and actual behavior of the people in the organization inevitably affect the organization's ability to achieve its aims. As a consequence, an understanding of the behavior of people in organizations is key to management that is effective in achieving the organization's objectives.

A central issue in this respect is that achieving organizational goals typically is a collective effort. Most of the work in organizations is performed by individuals working together with others in the organization. More often than not, these people are explicitly dependent on each others actions, for instance when they work in teams. And rightly so. A key advantage of groups over single individuals is that group performance may benefit from the diversity of perspectives, knowledge, and expertise that different individuals may bring to the scene. Indeed, work is often organized in team-based ways to allow organizations to benefit from the diversity of backgrounds of its members. People with different backgrounds, for instance with different educational, functional, or cultural backgrounds, may know different things that are relevant to the task at hand. As a consequence, groups with a diverse membership may have a greater pool of information, knowledge, and expertise to work from than individuals, or than groups with a more homogeneous membership. In principle, therefore, diverse groups should be able to outperform both individuals and more homogeneous groups in terms of the 
quality of their decisions, their creativity, and their ability to innovate. In practice, however, groups often seem to have great problems in harvesting the potential benefits of their diversity. Obviously, then, understanding and managing the effects of work group diversity poses a great challenge to research and practice in organizational behavior.

This is the issue I will talk about today: work group diversity and its effects on the performance of work groups and teams in organizations. Clearly, work group diversity is an issue that is central to organizational behavior. It also is an issue that allows me to illustrate the kind of approach I believe we should take in the study of organizational behavior. As more than an afterthought, it is also an issue that is particularly relevant to work in academia, and especially to work in a multi-disciplinary business school environment. 


\section{Work Group Diversity: A Brief Review of the Field}

First, let me introduce the field of research to you. l'll start with the concept of diversity itself. The concept of diversity refers to a characteristic of a group or organization. It reflects the degree to which there are objective or subjective differences between people within the group (van Knippenberg \& Schippers, 2007). There are three aspects of the conceptualization of diversity that I would like to emphasize. First, diversity is a group characteristic, not an individual characteristic. Diversity deals with how differences between group members affect group functioning, not with how being different from others affects individual functioning. For the latter question, we have the field of relational demography (e.g., Chattopadhyay, Tluchowska, \& George, 2004). Second, the study of diversity is not about explaining differences between different organizational groups. It is about explaining how the extent to which there are differences between members of a group affect group functioning. To make this more concrete in an example, let's take gender diversity. Diversity research is not about understanding differences between the performance of men and women in organizations; it is about understanding how work groups with both male and female members may differ in their performance from groups that are all-male or all-female in their membership. Third, issues of diversity are at least as much about subjective differences as they are about objective differences. To a large extent, the differences people believe exist between group members are as important in causing the effects of diversity as the differences that may exist in terms of more objective standards. To stick to the gender example: If a mixed-gender group performs more poorly than a samegender group, biased perceptions of the own and the other gender may be at least as important in causing these effects as any objective differences that may exist between men and women.

It should also be clear from the definition of diversity that diversity in principle may refer to any dimension of differentiation - whether this be age or income, skin color or hair color, sexual preference or toothpaste preference. In practice, however, diversity research and practice has mainly concerned itself with differences in gender, age, ethnicity, tenure, educational background, and functional background (Milliken \& Martins, 1996). No matter which dimension of diversity is studied, however, the key question in diversity research has always been how differences between work group members affect group process and performance - the very issue I am talking about today. 
When I first started to get a serious interest in diversity research around the year 2000, the state of the field was beautifully captured by an influential review by Williams and O'Reilly (1998). In short, it was a mess. Findings were all over the shop, and the field was lacking a unified theoretical framework to make sense of all of this. From the perspective of the discipline, this is not good. From the perspective of the individual researcher, however, things look different. An empirical and conceptual mess there for you to make sense of offers an attractive challenge. And one we happily accepted. However, in this respect I should note up front that I am not going to claim that we were able to clean up the mess. I do claim, though, that we made substantial progress in making sense of the mess, and in paving the way for diversity research to clean up the mess.

To explain this messy state of affairs, I first need to introduce the two main theoretical traditions in diversity research. In its attempts to understand the effects of work group diversity, diversity research has been guided by two theoretical perspectives: the social categorization perspective and the information/decision making perspective (Williams \& O'Reilly 1998). In short, the basic prediction of the social categorization perspective in diversity research is that diversity is bad for group performance. In sharp contrast, the basic prediction of the information/decision making perspective is that diversity is good for group performance.

\section{The Social Categorization Perspective}

Starting point for the social categorization perspective is the notion that people categorize others based on perceived similarities and differences. Others that are seen as similar to self tend to be categorized as ingroup - part of the own group, part of "us." Others that are seen as dissimilar to self tend to be categorized as outgroup - as part of another group, as part of "them." The social categorization perspective thus proposes that in diverse groups, differences between group members may lead group members to distinguish subgroups within the work group - differentiating an ingroup of people similar to self from an outgroup of others that are different from self - in a very real sense differentiating "us" and "them." A large body of research in social psychology suggests that such subgroup categorizations are not without consequence. People typically like ingroup more than outgroup, trust ingroup more than outgroup, and are more willing to cooperate with ingroup than with outgroup. The social categorization perspective in diversity research therefore predicts that diversity disrupts group process because group members are less prone to like, trust, and cooperate with 
dissimilar others. The ultimate effect of this is that diverse groups should perform more poorly than more homogenous groups in which the members are more similar to each other.

To illustrate this with a simple example-let's stick to the gender example-consider the case of a gender-diverse team. The social categorization perspective would predict that gender differences give rise to subgrouping. Male team members would cluster together, and female team members would cluster together. Male and female subgroups would also be biased in their perception of ingroup and outgroup. Male members would prefer to work with male team mates, trust male team mates more, and cooperate more with male team mates. Female team members would show a similar preference for other female team members. The resultant lack of communication and cooperation between male and female team members would be bad for group functioning. Indeed, it would lead this gender-diverse team to perform more poorly than an otherwise comparable gender-homogeneous team.

\section{The Information/Decision Making Perspective}

The information/decision making perspective arrives at a quite different prediction. Starting point for this perspective is the notion that diverse groups possess a broader range of task-relevant knowledge, skills, and abilities. As a consequence of their diversity, members are also more likely to have different opinions and perspectives on the task at hand. This gives diverse groups a larger pool of resources that may be helpful in task performance. It may also set the stage for more creativity and innovation, because the need to integrate diverse information and reconcile diverse perspectives may stimulate creative thinking. In short, using their diversity as an informational resource, diverse groups may outperform more homogeneous groups.

Going back to the example of a gender-diverse team: The information/decision making perspective would predict that gender differences may be associated with valuable differences in task-relevant information and perspectives. Male and female group members may through differences in prior experiences, different backgrounds, or through other gender-related differences have different information and different opinions that are relevant to the group's task. By exchanging and integrating these informational resources, this gender-diverse team may reach a richer, more in-depth understanding of the task. As a consequence, the team may be able to generate more creative and higher-quality solutions to problems, reach higher-quality decisions, or 
develop more innovative products than an otherwise comparable gender-homogeneous team.

\section{But Where is the Evidence?}

So much about the theoretical perspectives that have dominated the field. Now consider the actual support in empirical research for each of these perspectives. It does not matter whether you look at the state of the literature at the time Williams and O'Reilly reviewed the field -in 1998 - or at the current state of the literature as Michaela Schippers and I recently reviewed it (van Knippenberg \& Schippers, 2007). Plain and simple, neither the social categorization perspective nor the information/decision making perspective is reliably supported in empirical research. Each and every review of the literature has to come to the conclusion that diversity is neither reliably associated with positive effects nor with negative effects. This conclusion derives not only from narrative reviews, but also from meta-analyses that quantitatively integrate research findings (Bowers, Pharmer, \& Salas, 2000; Webber \& Donahue, 2001). In short, anyone who believes that diversity is mainly associated with positive effects is wrong. And anyone who believes that diversity is mainly associated with negative effects is wrong too.

The most common way to make sense of this seems to be to propose that clearly, obviously, the effects of diversity depend on the type of diversity. The negative effects of diversity that are caused by subgroupings and "us - them" thinking would be tied to dimensions of diversity that are typically associated with stereotypes and prejudice, such as gender, age, and ethnicity. The positive effects of diversity that are caused by the integration of diverse informational resources would be tied to dimensions of diversity that are typically associated with differences in knowledge and expertise, such as diversity in educational and functional background. The notion that this would explain the inconsistent findings in diversity research seems to be widely shared among diversity researchers (e.g., Mannix \& Neale, 2005). Too bad for these widely shared beliefs, but again they are wrong. Findings for any dimension of diversity that has been investigated in more than a few studies are inconsistent. Sometimes the dimension in question is associated with positive effects, sometimes with negative effects, and sometimes with no effects at all. Again this conclusion derives not only from narrative reviews, but also from meta-analyses that explicitly tested the role of diversity type (Bowers et al., 2000; Webber \& Donahue, 2001). 
The explanation for this is simple. A first thing to realize is that any dimension of diversity may be associated with meaningful differences in task-relevant information and perspectives. Such differences need not be tied to formal education or functional background but can derive from a host of differences in experiences and preferences that may be associated with all kinds of differences between people - with differences in demographic characteristics and in personality just as well as with differences in educational and functional background. At the same time, the ability to elicit subgroupings and stereotypes is not limited to differences in demographic characteristics. For an example, one need only to look at the stereotypes and prejudices that some people in this school hold about economists, psychologists, or sociologists to realize that such effects go beyond simple demographic differences. In short, all dimensions of diversity may elicit the effects described in the social categorization perspective. And all dimensions of diversity may elicit the effects described in the information/decision making perspective.

Carsten De Dreu, Astrid Homan, and I reached these conclusions in a conceptual paper we published a few years ago (van Knippenberg, De Dreu, \& Homan, 2004), and I truly believe these are two important observations for our understanding of diversity: Diversity is not uniformly associated with either positive or negative effects; and, making a distinction between types of diversity does not help us much in making sense of the effects of diversity. The obvious question of course then is, what does? Or put differently, can the perspectives on the positive and the negative effects of diversity be reconciled and integrated? - and if so, how? To answer this question, we need to more carefully consider the group processes through which diversity may affect group performance, and we need to take the contingencies of these processes into account. This is something that diversity research typically has not done much. In terms of the lingo of organizational behavior research: we need to more carefully look at mediating processes and moderating variables. By more than happy coincidence, Carsten De Dreu, Astrid Homan, and I proposed a model that does exactly that - the CategorizationElaboration Model (van Knippenberg et al., 2004). 


\section{The Categorization-Elaboration Model of Group Diversity and Performance}

In proposing the Categorization-Elaboration Model, we did not discard the social categorization and information/decision making perspectives. As I just discussed, neither perspective is supported in the form in which it is typically invoked. That does not mean that there is no value in these perspectives. Rather it implies - at least to us that we need more sophisticated developments of these perspectives - versions that are more up to speed with the state of the art in research in social categorization, information processing, and decision making outside the diversity arena. Moreover, to account for the effects of diversity, we cannot treat the social categorization perspective and the information/decision making perspective as separate perspectives. We need to integrate them. All this is exactly what we aimed to accomplish with the Categorization-Elaboration Model.

The observation that lies at the heart of the Categorization-Elaboration Model is that work groups are information processing systems (De Dreu, Nijstad, \& van Knippenberg, in press; Hinsz, Tindale, \& Vollrath, 1997). To arrive at task outcomes, group members exchange, process, and integrate parts of the information and knowledge available to them. We called this process elaboration of task-relevant information (van Knippenberg et al., 2004). To a certain extent, information elaboration is central to the performance of all task groups. It is of specific significance to diverse groups, however. This follows directly from the information/decision making perspective. In this perspective, the value of diversity to group functioning is seen in diversity as an informational resource. Clearly, for this informational resource to feed into group performance, it needs to be mobilized by the group. Task-relevant information needs to be exchanged and integrated. Group members need to think about the implications of different pieces of information and about the viability and compatibility of different perspectives. In short, groups need to engage in information elaboration to use the informational resource provided by the group's diversity. Only to the extent that groups engage in elaboration of task-relevant information and perspectives will they be able to harvest the potential benefits of their diversity (cf. van Ginkel \& van Knippenberg, in press). 
I believe this is a simple and straightforward proposition. At the same time, however, it is a proposition that had not really been articulated in diversity research. Until we introduced it, diversity research did not really incorporate measures of group information processing. The importance of the proposition that elaboration is the key process underlying the positive effects of diversity lies in the fact that it suggest that if we want to understand how to realize the positive effects of diversity, we should identify variables that may render information elaboration in diverse groups more likely.

\section{Stimulating Information Elaboration}

A first observation to make in this respect, is that some tasks are more knowledgeintensive than others. That is, some tasks require group members to process and integrate a lot of information, for instance the tasks faced by Research \& Development teams or by top management teams. These tasks are often non-routine, and appropriate solutions to task problems are ill-defined and require creative and careful integration of information. In short, elaboration of task-relevant information is of the essence. Other tasks, in contrast, are simple, straightforward, and routine with only very modest information processing requirements. Take for example simple production tasks. Such tasks require far less elaboration. Clearly then, diversity as an informational resource may make more of a difference in group performance for complex, nonroutine tasks than for simple, routine tasks (Bowers et al., 2000; Jehn, Northcraft, \& Neale, 1999; van Knippenberg et al., 2004). Thus, when we talk about the potential benefits of diversity, we should realize that these are likely to be limited to certain types of tasks or teams, if you wish.

Information elaboration is an effortful process. It takes time and energy to exchange and integrate diversity of information and perspectives. There is a large body of evidence from the study of individual information processing that such effortful processing is contingent on both motivation and ability: more motivated and more able individuals are more likely to engage in extensive processing of information (e.g., Chaiken \& Trope, 1999). The same should hold for groups as information processors. Diverse groups with more motivated and more able members should be more likely to harvest the benefits of their diversity. Initial evidence for this can be found in research by Lotte Scholten and colleagues (Scholten, van Knippenberg, Nijstad, \& De Dreu, 2007). Scholten and colleagues studied decision making groups with diversity of information in an experiment. They induced differences in processing motivation by holding some 
groups accountable for their decision making process while other groups were not held accountable. Process accountability is known to feed into the motivation to carefully consider information. As expected, accountable groups engaged in more elaboration of information and reached higher-quality decisions. In short, they made better use of their diversity of information than less motivated groups. This implies that an important aspect of managing work group diversity is managing group motivation. I expect that future research will show that the same holds for developing group members' ability to process and integrate information.

Motivation and ability may be important. However, perhaps the main challenge in managing information elaboration in diverse groups lies in the social categorization processes that diversity may set in motion. When group members are biased against fellow group members because they are different from them, this lowers the willingness to share information. It also lowers the openness to information and perspectives introduced by different others (cf. van Knippenberg, 1999). In other words, it reduces the elaboration of task-relevant information. A key element in the management of information elaboration in diverse groups thus is the management of social categorization processes.

We know, however, that the social categorization perspective in its most-invoked form does not hold in diversity research. Therefore, to understand the role of social categorization in information elaboration in diverse groups, we first need a better understanding of social categorization processes in diverse groups more generally.

\section{Refining Our View of Social Categorization Processes}

The Categorization-Elaboration Model provides this better understanding in two ways. First, by suggesting a more complex relationship between diversity and social categorization. Second, by proposing that social categorization per se should not be equated with disruptive intergroup processes.

As to the first, theory in diversity typically suggests a direct relationship between differences between people and social categorization processes. The greater the diversity in a group, the stronger the tendency for subgroups to form. This is not true. The key issue is whether a potential subgrouping is salient - that is, whether it is activated in people's mind. We know from research outside the diversity arena that there is no one-on-one relationship between differences between people and the 
salience of categorizations (Turner, Hogg, Oakes, Reicher, \& Wetherell, 1987). Salience is contingent on a number of factors (for a more elaborate discussion, see van Knippenberg et al., 2004). One of these I highlight here, because it has more recently also been studied in diversity research and therefore best allows me to make the more general point I want to make: To understand social categorization processes in diversity, we need to understand what makes potential subgroupings salient and not just focus on the extent to which there are differences between group members.

An important influence in this respect is comparative fit (Turner et al., 1987). Comparative fit refers to the extent to which a categorization would result in groupings with high similarity between the members of a group as well as in large differences between groups. This is important, because people think in terms of groups because it helps make sense of the world. It helps summarize what individuals have in common, and what distinguishes certain groups of people from other groups of people. People are therefore more likely to think in terms of a particular categorization when this categorization seems to adequately capture similarities and differences between people. That is, when it has high comparative fit. The important implication of the notion of comparative fit is that we should consider the influence of more than one dimension of diversity simultaneously. This is something that is typically not done in diversity research and practice. Let me illustrate the notion of comparative fit with an example, returning again to our gender diverse team.

Suppose that our gender diverse team is composed of people with different educational backgrounds. Roughly half the members of the team have a background in economics, the other half have a background in sociology. If it so happens that all the economists are female, while all the sociologists are male, focusing on gender differences also captures differences in educational background. In that sense, thinking in terms of a grouping of female economists and male sociologists nicely summarizes some of the differences between people in the team. In a sense, the combination of gender and educational background creates a faultline along which the team may be divided into subgroups (Lau \& Murnighan, 1998). Now compare this to the situation in which differences in educational background cross-cut gender differences - a situation in which there are both male and female economists and both male and female sociologists in the team. In this case, a grouping based on gender does not capture differences in educational background. Its comparative fit is lower than in the former case. Therefore, its salience should be lower than in the former case. Accordingly, social 
categorization processes are more likely to disrupt the functioning of the team in the former case than in the latter case.

This understanding of the effects of diversity in terms of comparative fit and faultlines is an understanding we can only reach when we do not consider dimensions of diversity in isolation. We need to consider the influence of different dimensions of diversity in combination. After all, both teams in our example are equally gender diverse. They are also equally diverse in terms of educational background. The differences lies not in diversity on each of these dimensions per se, but in the salience of these differences.

Now let me use some of our own research to illustrate how these notions may be used to predict when diversity may engender social categorization processes that disrupt the elaboration of task-relevant information. Lead author of this study is Astrid Homan (Homan, van Knippenberg, Van Kleef, \& De Dreu, 2007a). The purpose of this study was to show how gender diversity and diversity in the task-relevant information available to group members may combine to affect group processes - much like in our example of the economist and sociologists in our gender-diverse team. The main point was to show that elaboration would not suffer from gender diversity when differences in background information and gender differences cross-cut each other, while elaboration would suffer from gender diversity when differences in background information and gender differences combined to form a faultline.

What we did is the following. We invited groups of four people into our lab for an experiment. Some of these groups were all-male. Others were all-female. Yet others consisted of two male and two female members. In this way we could test the effects of gender diversity. The groups were required to complete a decision making assignment. For this assignment, they received a package of background information. This information was necessary to reach an optimal decision. In half of the groups, each member received the full package of information. In the other half of the groups, some parts of the information were only given to two of the members, while other parts of the information were only given to the two other members. So, these latter groups had diversity in informational background, and needed to exchange information to make the full package of information available to all group members. The most important point is that there were two different ways in which we combined gender diversity and informational diversity. 
In half of the groups that were both gender diverse and informationally diverse, samegender members always received the same package of information, and differentgender members received different information. In other words, gender and information combined formed a faultline. In the other half of the groups, gender differences cross-cut informational differences. One male member and one female member received the one package of information, the other male member and the other female member received the other package of information. To measure team process, we used audio-video recordings for the observation of behavior and questionnaires for group members to report about team process. The expectation was that in the faultline condition, but not in the cross-cutting condition, diversity would be salient. Accordingly, diversity should be more likely to engender social categorization processes in the faultline condition. This should be evident in poorer team climate, more conflict among team members, and less information elaboration in the faultine condition than in the cross-cutting condition. This is exactly what we found.

This study nicely illustrates the value added of a focus on diversity salience rather than on differences per se. In the cross-cutting condition and the faultline condition groups were equally gender diverse. Groups were also equally informationally diverse. Focusing on each of these dimensions in isolation or in additive models would not allow you to understand the differences in group processes between the two conditions. Taking a salience approach and focusing on the influence of the specific configuration of gender and informational differences in combination, however, allows us to predict and understand the effects of diversity.

For those of you who are more hesitant to accept findings from laboratory experiments, and want evidence from what sometimes is called the "real world", we have that too. We used the same faultline approach in a study of top management teams in the UK (van Knippenberg, Dawson, West, \& Homan, 2006). In this study, we show that a focus on a faultline formed by gender and professional background allowed us to predict organizational performance, whereas a focus on each diversity dimension separately did not.

As an aside, this also allows me to make a point I believe is important. In behavioral research, we need lab experiments to prove causality. We also need field studies to show that the same relationships may be observed outside of the lab. Ideally, therefore, we would test the same hypotheses using both methods. This is what we aim to do 
whenever possible. And this has allowed us to conclude that what we find in the lab, we typically also find in the field (e.g., van Knippenberg \& van Knippenberg, 2005; van Knippenberg \& van Leeuwen, 2001).

The Categorization-Elaboration Model not only offers a different view of the relationship between diversity and social categorization; it also emphasizes the fact that social categorization should not be equated with disruptive intergroup processes. Social categorization may set the stage for more negative responses to people that are seen as outgroup. It does not inevitably do so, however. Let's go back to our gender-diverse team. It may make sense to a member of this group to think of the team in terms of gender differences. Team members may associate the male members of the team with other behavior and other expertise than the female members of the team. This could also lead them to prefer to work with same-gender team members over working with othergender team members - but it need not. Team members may also think of the team in terms of gender differences without feeling that the own gender is in some way superior to the other gender. In that sense, the problem with diversity is not that it may lead to social categorization per se. The problem with diversity is that social categorization may lead to biases against other groups. This is an important observation, because it suggests that the real challenge is not to prevent social categorization. The real challenge is to prevent intergroup biases. An understanding of the effects of diversity, and the management of diversity, thus involves understanding the factors that render it more or less likely that social categorization results in intergroup biases.

Before I address this issue in more detail, let me summarize my discussion of the Categorization-Elaboration Model in a figure (see Figure 1). This figure shows that diversity - any dimension of diversity - may engender a process of information elaboration that benefits group performance. Diversity may also engender social categorization, however. When this social categorization results in intergroup biases, it disrupts elaboration processes and thus stands in the way of group performance. Managing diversity thus requires stimulating elaboration as well as preventing social categorization processes from resulting in intergroup biases. I have already discussed the role of motivation and ability in stimulating elaboration. Wendy van Ginkel in particular has done quite some work on other factors that may stimulate elaboration in groups with distributed information. In short, what her work shows is that people's mental models of the team and of the task - their understanding of the team and the task - influence the extent to which they engage in information elaboration (e.g., van Ginkel \& van Knippenberg, in press). 


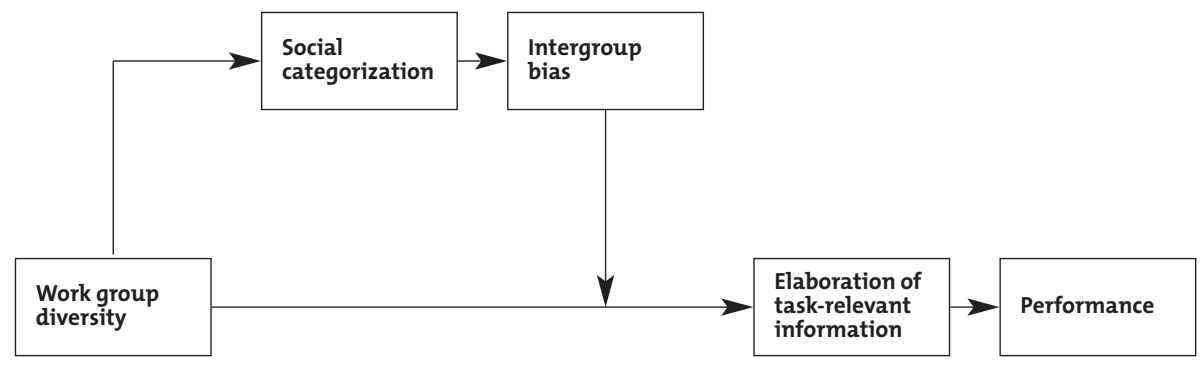

The question I have left unanswered so far is how to prevent intergroup biases. The Categorization-Elaboration Model suggests that there are basically two ways to do so. Prevent social categorization from occurring, or prevent the translation of social categorization into intergroup bias. Research on faultlines suggest that the former may be aided by carefully composing teams to let different dimensions of diversity cross-cut each other. In practice, I suspect that the number of cases in which this is a realistic option is limited. More often than not, team composition will already be a given. In other cases there will be insufficient opportunity to take faultlines into account when composing the team or bringing new members into the team. From a more applied point of view, it thus might make more sense to take salient differences as a given. From that perspective, we should focus on the question of what affects responses to salient diversity within a team.

In this respect, we have recently proposed a core role for diversity beliefs - group members' beliefs about diversity, and specifically about the extent to which diversity has value for the group or is a burden to the group (van Knippenberg \& Haslam, 2003; van Knippenberg, Haslam, \& Platow, 2007; van Knippenberg \& Schippers, 2007). I will use the remainder of this address to introduce the concept of diversity beliefs to you, and to discuss the role diversity beliefs may play in our understanding of diversity, and in our ability to manage diverse groups. 


\section{Diversity Beliefs}

The basic point I want to make here is that what you believe diversity does makes a difference. The social categorization perspective recognizes that people may hold biases against dissimilar others that may inform responses to diversity. Diversity research thus has acknowledged the role of beliefs about different others. It has paid far less attention to the potential influence of the beliefs that individuals may hold about diversity itself. Based on stereotypes, prior experience, and a host of other factors, people may hold beliefs about the effects of diversity on work group functioning. We called such beliefs diversity beliefs - beliefs about the value of diversity to work group functioning (van Knippenberg \& Haslam, 2003; van Knippenberg et al., 2007). When people believe that diversity has benefits for group performance, for instance because they believe that diversity is associated with a larger pool of knowledge and perspectives, they may value diverse groups more than homogeneous groups. We propose that if group members believe in the value of diversity, they are more likely to positively engage with diversity to realize its benefits. In contrast, if group members believe that diversity is a burden, responses to a diverse group will be less positive. In other words, we propose that valuein-diversity beliefs affect group members' responses to salient differences within their group. If group members believe in the value of diversity, diversity is less likely to elicit intergroup biases, and more likely to lead to elaboration, than when group members believe diversity is problematic.

Again, I believe this is a simple and straightforward idea, but I believe it is important, and for some reason it has not really appeared on the agenda of diversity research until recently (cf. van Knippenberg \& Schippers, 2007). The importance of the idea lies in that it suggests that to understand the effects of diversity, we also need to understand the role of group members' understanding of diversity. It also suggest that to manage diversity, we may need to influence group members' beliefs about diversity. Let me illustrate the role of diversity beliefs with some of our own research.

In the first study we did on diversity beliefs, Alex Haslam, Michael Platow, and I (van Knippenberg et al., 2007) aimed to show that individual responses to work group diversity are contingent on their beliefs about diversity. To do so, we focused on group members' identification with their group. The typical reading of the social categorization perspective would suggest that diversity would lower identification, because people will not identify with a group of diverse others. Our hypothesis was that 
this may hold for individuals who believe homogeneity is preferable, but not for people who believe in the value of diversity. In a straightforward test we surveyed members of a variety of work groups. We asked them to report about the gender composition of their group, so we could compute gender diversity. We also measured their beliefs about the value in gender diversity and their group identification. As predicted, we found that gender diversity was negatively related to identification for people believing in the value of homogeneity, whereas it was positively related to identification for people believing in the value of gender diversity. Ergo: what diversity does is what you make of it.

I already noted that I value a multimethod approach in research. Where possible, we aim to test the same hypothesis in controlled lab experiments as well as in surveys of people in organizations. This is also what we did for this particular study. To complement the survey, we also conducted a lab experiment in which we induced independent variations of diversity beliefs and group diversity versus homogeneity. In this experiment we found the same as in the field. Diversity beliefs moderated the relationship between diversity and identification. When people believed in the value of diversity, they identified more with a diverse group than with a homogeneous group.

This study provides important first evidence for the role of diversity beliefs in moderating the effects of diversity. Ideally, of course, we'd also show that the effect of diversity on performance is contingent on diversity beliefs. This is exactly what we aimed to show in a study in which Astrid Homan took the lead (Homan, van Knippenberg, Van Kleef, \& De Dreu, 2007b). We used a similar experimental set-up as I described before. In our lab, we assigned people to four-person gender-diverse groups. The groups were to work on a decision making task, using the background information provided to them. In half of the groups, all members received the full package of information. In the other half of the groups, different-gender members always received different information. Informational differences could thus be expected to render gender diversity salient. Indeed, note that this is the faultline condition from the study by Homan and colleagues I discussed earlier. Equally important, especially groups in this condition needed to engage in information elaboration to put their informational resources to good use. We predicted that whether or not they would do so would be contingent on diversity beliefs. Through a cover story, we led half of the groups to believe in the value of gender diversity. The other half of the groups we led to believe that gender diversity would actually be bad for group performance. We expected that 
these differences in diversity beliefs would especially affect groups with diversity of information - the groups that relied more on information elaboration for high-quality decisions. This is exactly what we found.

When dealing with informational diversity, groups that believed in the value of gender diversity engaged in more information elaboration and reached higher quality decisions than groups that believed that gender diversity was bad. Such differences were not present in groups that did not have to deal with informational diversity. What this study shows is that whether salient differences do not necessarily disrupt group information elaboration and performance - they do not when group members believe in the value of diversity.

Sharp observers among you may note that all the groups in this study were gender diverse. Therefore, we do not really show that gender diversity beliefs moderate the effects of gender diversity. We show that gender diversity beliefs affect the performance of gender diverse groups. Fair enough. For those sharp observers then, and for those of you who also demand evidence from the field, let me note that a study by Jana Raver and myself (Raver \& van Knippenberg, 2007) may put your minds at ease. In a survey of student project teams, we assessed gender diversity, gender diversity beliefs, information elaboration, and group performance. Results showed that the relationship between gender diversity and elaboration was contingent on gender diversity beliefs as predicted. Elaboration in turn predicted group performance.

What these studies suggest then, is that an important part of managing diversity may be managing people's understanding of diversity. If we can convince people of the value of diversity, diverse groups are more likely to benefit from their diversity and less likely to suffer the potential negative consequences of diversity. The next step thus is to identify the determinants of diversity beliefs - and more specifically ways to influence diversity beliefs. In this respect, we have started to investigate how team leaders may influence group members understanding of diversity. Research by Wendy van Ginkel yields promising first evidence. It shows that team leaders may influence group members' mental models of diversity, and in this way influence the effect of diversity on group performance. I am the first to note that this is only first evidence. It does suggest, however, that part of the management of diversity may be team leadership that persuades group members of the value of diversity. 


\section{Understanding Diversity - In Conclusion}

To conclude, let me just recap a few issues. To understand and manage the effects of diversity, we need to carefully consider the group processes we are trying to manage, and the contingencies of these processes. First and foremost, to harvest the benefits of diversity we need to stimulate the elaboration of task-relevant information. In this respect, it is essential that we also prevent salient differences to engender intergroup biases. While several factors are important in this respect, one of the more important one's is group members' understanding of diversity. We need to realize that management scholars are not the only ones thinking about diversity. People in diverse groups do to, and what they believe makes a difference.

Interestingly and importantly, these are all issues that emerged relatively recently on the research agenda (cf.van Knippenberg \& Schippers, 2007). In that sense, even after more than 50 years of diversity research (cf. Williams \& O'Reilly, 1998), we have really only just begun. The challenge to clean up the mess in diversity research is still there.

That suits me just fine. 


\section{A Word of Thanks}

I received my PhD from Leiden University, where custom has it that you cannot thank your PhD advisor in the acknowledgements to your dissertation, because advisors are only doing their work. In a similar vein, the American Psychological Association which has a huge influence on publication habits in my field has a rule that you cannot thank editors or reviewers for their efforts, because they are only doing their work. I thus have been thoroughly socialized into not thanking people for doing their work.

In that spirit, rather than thanking them, l'd like to extent my compliments for their excellent decision to offer me a position at RSM Erasmus University to Prof. Barbara Krug, chair of the selection committee, to Prof. Berend Wierenga, Director of ERIM at the time, and to Prof. Paul Verhaegen, dean at the time. Similar compliments are due to Prof. Ale Smidts, current director of ERIM, and to Prof. Han van Dissel, successor of Paul Verhaegen as dean, for their continuous support for the development of research and teaching in organizational behavior. Looking back on that decision, I hope you are satisfied with the outcome so far.

Having said that, I do realize that it is customary to end an inaugural address with a word of thanks. Looking back at my working life for the past decade or so, I happily do so. At the risk of offending several people, however, l'd like to reserve this word of thanks to acknowledge three people in particular.

Eric, if I would consider for how long we have been friends, I'd start feeling old. In our time in Leiden, your friendship helped me to survive the gang warfare that was going on at the time in our department. It also made work so much more enjoyable. And if we ever find the time to convert this huge pile of data on comparability into a series of papers, it could even lead to a serious contribution to the literature. Most importantly, however, hanging out with you makes life more fun, and I hope we can keep this on the agenda for at least as long as it has been there so far. 
David, I know you will criticize me afterwards for using the M-word, but you are an inspiring maniac. Working with you is as inspiring as it is productive. No doubt it has also lead to too many ambitious plans and produced far more work than is good for us. So be it. More importantly, you are also a great friend and I thank you for being there for me.

Barbara, your support and wise advice have made working life much easier. Your sharp insights have also helped to make it more productive. And your wonderfully twisted sense of humor ensured that it was not only productive but also extremely enjoyable. Thank you for making doing research such a rewarding experience.

Ik heb gezegd. 


\section{References}

Bowers, C., Pharmer, J. A., \& Salas, E. (2000). When member homogeneity is needed in work teams: A meta-analysis. Small Group Research, 31, 305-327.

Chaiken, S., \& Trope, Y. (1999). Dual process theories in social psychology. New York: Guilford Press.

Chattopadhyay, P., Tluchowska, M., \& George, E. (2004). Identifying the ingroup: A closer look at the influence of demographic dissimilarity on employee social identity. Academy of Management Review, 29, 180-202.

De Dreu, C. K. W., Nijstad, B. A., \& van Knippenberg, D. (in press). Motivated information processing in group judgments and decision making. Personality and Social Psychology Review.

Hinsz, V. B., Tindale, R. S., \& Vollrath, D. A. (1997). The emerging conceptualization of groups as information processes. Psychological Bulletin, 121, 43-64.

Homan, A. C., van Knippenberg, D., van Kleef, G. A., \& De Dreu, C. K. W. (2007a). Interacting dimensions of diversity: Cross-categorization and the functioning of diverse work groups. Group Dynamics, 11, 79-94.

Homan, A. C., van Knippenberg, D., van Kleef, G. A., \& De Dreu, C. K. W. (2007b). Bridging faultlines by valuing diversity: Diversity beliefs, information elaboration, and performance in diverse work groups. Journal of Applied Psychology, 92, 1189-1199.

Jehn, K. A., Northcraft, G. B., \& Neale, M. A. (1999). Why differences make a difference: A field study of diversity, conflict, and performance in workgroups. Administrative Science Quarterly, 44, 741-763.

Lau, D. C., \& Murnighan, J. K. (1998). Demographic diversity and faultlines: The compositional dynamics of organizational groups. Academy of Management Review, 23, 325-340. 
Mannix, E., \& Neale, M. A. (2005). What differences make a difference? The promise and reality of diverse teams in organizations. Psychological Science in the Public Interest, $6,31-55$.

Milliken, F., \& Martins, L. (1996). Searching for common threads: Understanding the multiple effects of diversity in organizational groups. Academy of Management Review, $21,402-433$.

Raver, J. L., \& van Knippenberg, D. (2007, April). Openness to diversity and the informational benefits of gender diversity. Paper presented at the $22^{\text {nd }}$ Annual Conference of the Society for Industrial and Organizational Psychology, New York.

Scholten, L., van Knippenberg, D., Nijstad, B. A., \& De Dreu, C. K. W. (2007). Motivated information processing and group decision making: Effects of process accountability on information sharing and decision quality. Journal of Experimental Social Psychology, 43, 539-552.

Turner, J. C., Hogg, M. A., Oakes, P. J., Reicher, S. D., \& Wetherell, M. S. (1987). Rediscovering the social group. A self-categorization theory. Oxford, UK: Blackwell.

van Ginkel, W., \& van Knippenberg, D. (in press). Group information elaboration and group decision making: The role of shared task representations. Organizational Behavior and Human Decision Processes.

van Knippenberg, B., \& van Knippenberg, D. (2005). Leader self-sacrifice and leadership effectiveness: The moderating role of leader prototypicality. Journal of Applied Psychology, 90, 25-37.

van Knippenberg, D. (1999). Social identity and persuasion: Reconsidering the role of group membership. In D. Abrams \& M. A. Hogg (Eds.), Social identity and social cognition, (pp. 315-331). Oxford, UK: Blackwell.

van Knippenberg, D., Dawson, J. F., West, M. A., \& Homan, A. C. (2006, August). Top management team diversity: Faultines, clarity of objectives, and organizational performance. Paper presented at the Annual Meeting of the Academy of Management, Atlanta, GA. 
van Knippenberg, D., De Dreu, C. K. W., \& Homan, A. C. (2004). Work group diversity and group performance: An integrative model and research agenda. Journal of Applied Psychology, 89, 1008-1022.

van Knippenberg, D., \& Haslam, S. A. (2003). Realizing the diversity dividend: Exploring the subtle interplay between identity, ideology, and reality. In S. A. Haslam, D. van Knippenberg, M. J. Platow, \& N. Ellemers (Eds.), Social identity at work: Developing theory for organizational practice, (pp. 61-77). New York: Psychology Press.

van Knippenberg, D., Haslam, S. A., \& Platow, M. J. (2007). Unity through diversity: Value-in-diversity beliefs as moderator of the relationship between work group diversity and group identification. Group Dynamics, 11.

van Knippenberg, D., \& Schippers, M. C. (2007). Work group diversity. Annual Review of Psychology, 58, 515-541.

van Knippenberg, D., \& van Leeuwen, E. (2001). Organizational identity after a merger: Sense of continuity as the key to post-merger identification. In M. A. Hogg \& D. J. Terry (Eds.), Social identity processes in organizational contexts, (pp. 249-264). Philadelphia, PA: Psychology Press.

Webber, S. S., \& Donahue, L. M. (2001). Impact of highly and less job-related diversity on work group cohesion and performance: A meta-analysis. Journal of Management, 27, 141-162.

Williams, K. Y., \& O’Reilly, C. A. (1998). Demography and diversity in organizations: A review of 40 years of research. Research in Organizational Behavior, 20, 77-140. 


\section{Erasmus Research Institute of Management (ERIM)}

Inaugural Addresses Research in Management Series

ERIM Electronic Series Portal: http://hdl.handle.net/1765/1

Balk, B.M., The residual: On monitoring and Benchmarking Firms, Industries and Economies with respect to Productivity, 9 November 2001, EIA-07-MKT, ISBN 90-5892-018-6, http://hdl.handle.net/1765/300

Benink, H.A., Financial Regulation; Emerging from the Shadows, 15 June 2001, EIA-02-ORG, ISBN 90-5892-007-0, http://hdl.handle.net/1765/339

Boons, A.N.A.M., Nieuwe Ronde, Nieuwe Kansen: Ontwikkeling in Management Accounting \& Control, 29 September 2006, ElA-2006--029-F\&A, ISBN 90-5892-126-3, http://hdl.handle.net/1765/8057

Bruggen, G.H. van, Marketing Informatie en besluitvorming: een interorganisationeel perspectief, 12 October 2001, EIA-06-MKT, ISBN 90-5892-016-X, http://hdl.handle.net/1765/341

Commandeur, H.R., De betekenis van marktstructuren voor de scope van de onderneming. 05 June 2003, EIA-022-MKT, ISBN 90-5892-046-1, http://hdl.handle.net/1765/427

Dale, B.G., Quality Management Research: Standing the Test of Time; Richardson, R., Performance Related Pay-Another Management Fad?; Wright, D.M., From Downsize to Enterprise: Management Buyouts and Restructuring Industry. Triple inaugural address for the Rotating Chair for Research in Organisation and Management. March 28 2001, EIA-01-ORG, ISBN 90-5892-006-2, http://hdl.handle.net/1765/338

Dekimpe, M.G., Veranderende datasets binnen de marketing: puur zegen of bron van frustratie?, 7 March 2003, EIA-17-MKT, ISBN 90-5892-038-0, http://hdl.handle.net/1765/342 
Dissel, H.G. van, “Nut en nog eens nut" Over retoriek, mythes en rituelen in informatiesysteemonderzoek, 15 February 2002, EIA-08-LIS, ISBN 90-5892-018-6, http://hdl.handle.net/1765/301

Dul, J., "De mens is de maat van alle dingen" Over mensgericht ontwerpen van producten en processen., 23 May 2003, EIA-19-LIS, ISBN 90-5892-038-X, http://hdl.handle.net/1765/348

Groenen, P.J.F., Dynamische Meerdimensionele Schaling: Statistiek Op De Kaart, 31 March 2003, EIA-15-MKT, ISBN 90-5892-035-6, http://hdl.handle.net/1765/304

Hartog, D.N. den, Leadership as a source of inspiration, 5 October 2001, EIA-05-ORG, ISBN 90-5892-015-1, http://hdl.handle.net/1765/285

Heck, E.van, Waarde en Winnaar; over het ontwerpen van electronische veilingen, 28 June 2002, EIA-10-LIS, ISBN 90-5892-027-5, http://hdl.handle.net/1765/346

Jong, A. de, De Ratio van Corporate Governance, 6 October 2006, EIA-2006-028-F\&A, ISBN 90-5892-128-X, http://hdl.handle.net/1765/8046

Kaptein, M., De Open Onderneming, Een bedrijfsethisch vraagstuk, and Wempe, J., Een maatschappelijk vraagstuk, Double inaugural address, 31 March 2003, EIA-16-ORG, ISBN 90-5892-037-2, http://hdl.handle.net/1765/305

Kroon, L.G., Opsporen van sneller en beter. Modelling through, 21 September 2001, EIA-03-LIS, ISBN 90-5892-010-o, http://hdl.handle.net/1765/340

Magala, S.J., East, West, Best: Cross cultural encounters and measures, 28 September 2001, EIA-04-ORG, ISBN 90-5892-013-5, http://hdl.handle.net/1765/284

Meijs, L.C.P.M., The resilient society: On volunteering, civil society and corporate community involvement in transition, 17 September 2004, EIA-2004-024-ORG, ISBN 90-5892-000-3, http://hdl.handle.net/1765/1908 
Osselaer, S.M.J.van, Of Rats and Brands: A Learning-and-Memory Perspective on Consumer Decisions, 29 October 2004, EIA-2003-023-MKT, ISBN 90-5892-074-7, http://hdl.handle.net/1765/1794

Pau, L-F., The Business Challenges in Communicating, Mobile or Otherwise, 31 March 2003, EIA-14-LIS, ISBN 90-5892-034-8, http://hdl.handle.net/1765/303

Peccei, R., Human Resource Management And The Search For The Happy Workplace. January 15, 2004, EIA-021-ORG, ISBN 90-5892-059-3, http://hdl.handle.net/1765/1108

Pelsser, A.A.J., Risico en rendement in balans voor verzekeraars. May 2 2003, EIA-18-F\&A, ISBN 90-5892-041-o, http://hdl.handle.net/1765/872

Rotmans, J., Societal Innovation: between dream and reality lies complexity. June 3 2005, EIA-2005-026-ORG, ISBN 90-5892-105-0, http://hdl.handle.net/1765/7293

Smidts, A., Kijken in het brein, Over de mogelijkheden van neuromarketing, 25 October 2002, EIA-12-MKT, ISBN 90-5892-036-4, http://hdl.handle.net/1765/308

Smit, H.T.J., The Economics of Private Equity, 31 March 2003, EIA-13-LIS, ISBN 90-5892-033-X, http://hdl.handle.net/1765/302

Stremersch, S., Op zoek naar een publiek...., April 15 2005, EIA-2005-025-MKT, ISBN 90-5892-084-4, http://hdl.handle.net/1765/1945

Verbeek, M., Onweerlegbaar bewijs? Over het belang en de waarde van empirisch onderzoek voor financierings- en beleggingsvraagstukken, 21 June 2002, EIA-09-F\&A, ISBN 90-5892-026-7, http://hdl.handle.net/1765/343

Waarts, E., Competition: an inspirational marketing tool, 12 March 2004, EIA-2003-022-MKT, ISBN 90-5892-068-2, http://ep.eur.nl/handle/1765/1519

Wagelmans, A.P.M., Moeilijk Doen Als Het Ook Makkelijk Kan, Over het nut van grondige wiskundige analyse van beslissingsproblemen, 20 September 2002, EIA-11-LIS, ISBN 90-5892-032-1, http://hdl.handle.net/1765/309 
Wynstra, J.Y.F., Inkoop, Leveranciers en Innovatie: van VOC tot Space Shuttle, February 17 2006, EIA-2006-027-LIS, ISBN 90-5892-109-3, http://hdl.handle.net/1765/7439 
Daan van Knippenberg is Professor of Organizational Behavior at RSM Erasmus University, Erasmus University Rotterdam, The Netherlands. His research interests include work group performance, especially work group diversity and group decision making, leadership, in particular the roles of self and identity, and of emotions, and social identity processes in organizations. In his inaugural address he argues that the effects of work group diversity on group performance should be understood in terms of two processes that have independent and interactive effects: elaboration of task-relevant information and social categorization. He outlines how an integrative model of these processes may explain inconsistent findings in diversity research and provide clear directions for the management of diverse groups. In this respect, he advocates in particular attention for group members' understanding of work group diversity. Daan van Knippenberg is co-founder of the Erasmus Centre for Leadership Studies, and Associate Editor of Organizational Behavior and Human Decision Processes and of Journal of Organizational Behavior. His research is published in such academic outlets as Journal of Applied Psychology, Organizational Behavior and Human Decision Processes, and Annual Review of Psychology.

The Erasmus Research Institute of Management (ERIM) is the Research School (Onderzoekschool) in the field of management of the Erasmus University Rotterdam. The founding participants of ERIM are RSM Erasmus University and the Erasmus School of Economics. ERIM was founded in 1999 and is officially accredited by the Royal Netherlands Academy of Arts and Sciences (KNAW). The research undertaken by ERIM is focussed on the management of the firm in its environment, its intra- and inter-firm relations, and its business processes in their interdependent connections.

The objective of ERIM is to carry out first rate research in management, and to offer an advanced doctoral programme in Research in Management. Within ERIM, over two hundred senior researchers and PhD candidates are active in the different research programmes. From a variety of academic backgrounds and expertises, the ERIM community is united in striving for excellence and working at the forefront of creating new business knowledge.

Inaugural Addresses Research in Management contain written texts of inaugural addresses by members of ERIM. The addresses are available in two ways, printed and electronical. For other inaugural addresses see the website of ERIM (www.erim.eur.nl). 